\title{
Efeito de doses de adubação orgânica na produção de palma forrageira
}

\author{
Maristênio Alves SANTANA ${ }^{1}$, Vitorio Antonio Pereira de SOUZA ${ }^{1 *}$, \\ Miryan Franciele Pereira SERPA ${ }^{1}$, Alex Aguiar LEDO $^{1}$, Arianna Santana de MENEZES² \\ ${ }^{1}$ Instituto Federal de Educação, Ciência e Tecnologia Baiano, Guanambi, BA, Brasil. \\ 2Programa de Pós-Graduação em Fitopatologia, Universidade Federal de Lavras, Lavras, MG, Brasil. \\ *E-mail: vitorioapsouza@gmail.com
}

(Orcid: 0000-0001-5088-1684; 0000-0003-3514-0241; 0000-0002-0673-2662; 0000-0002-6176-6363; 0000-0002-9267-0997)

Recebido em 19/06/2020; Aceito em 10/05/2021; Publicado em 16/05/2021.

\begin{abstract}
RESUMO: A palma forrageira representa excelente alternativa de cultivo para o semiárido brasileiro por adaptar-se bem as condições edafoclimáticas da região. O objetivo desse trabalho foi avaliar as características morfométricas e a produtividade de duas espécies de palma forrageira submetidas a diferentes doses de adubação orgânica. O delineamento experimental utilizado foi em blocos casualizados em esquema fatorial $4 \mathrm{x}$ 2, com 4 repetições, sendo quatro doses de adubação orgânica e duas espécies. As características avaliadas foram: comprimento do cladódio, largura do cladódio, número de cladódios, altura das plantas, altura total dos cladódios, área do cladódio, índice de área dos cladódios, produção de massa verde e produção de massa seca. Os dados foram submetidos a análise de variância. O teste de Tukey $(\mathrm{P}<0,05)$ foi usado para comparação das médias das espécies e para doses de adubo foram gerados gráficos a partir das regressões. Para as características morfométricas e de produção observou-se efeito significativo para as doses de esterco bovino sob todos os parâmetros analisados. A máxima produção de matéria seca foi observada, quando se aplicou $75 \mathrm{t} \mathrm{ha}^{-1}$ de esterco bovino. A palma 'Gigante' apresenta maior produção de matéria seca quando comparada a 'Sem espinho'.

Palavras-chave: Nopalea cochenillifera; Opuntia ficus-indica; semiárido.
\end{abstract}

\section{Effect of organic fertilization doses on forage palm production}

\begin{abstract}
The forage palm represents an excellent cultivation alternative for the Brazilian semi-arid, as it adapts well to the region's edaphoclimatic conditions. The objective of this work was to evaluate the morphometric characteristics and the productivity of two species of forage palm submitted to different doses of organic fertilization. The experimental design used was in randomized blocks in a $4 \times 2$ factorial scheme, with 4 replications, with four doses of organic fertilization and two species. The characteristics evaluated were: length of the cladode, width of the cladode, number of cladodes, plant height, total height of the cladodes, area of the cladode, index of the area of the cladodes, production of green mass and production of dry mass. The data were subjected to analysis of variance. The Tukey test $(\mathrm{P}<0.05)$ was used to compare the means of the species and for fertilizer doses, graphs were generated from the regressions. For the morphometric and production characteristics, a significant effect was observed for the doses of bovine manure under all parameters analyzed. Maximum dry matter production was observed when 75 t ha-1 of bovine manure was applied. The 'Gigante' palm has a higher production of dry matter when compared to 'Sem espinho'.

Keywords: Nopalea cochenillifera; Opuntia ficus-indica; semiarid.
\end{abstract}

\section{INTRODUÇÃO}

A Palma forrageira é uma cactácea de origem mexicana que apresenta alta capacidade de adaptação em regiões áridas e semiáridas do Brasil e do mundo, sob ambientes com altas temperaturas e solos diversos, em virtude das suas características anatômicas, morfológicas, fisiológicas e bioquímicas (SILVA et al., 2015; SOARES, 2017).

Existem 178 gêneros com 2.000 espécies distribuídas pelo mundo, porém dois gêneros possuem maior importância econômica, o Opuntia e o Nopalea (MARQUES et al., 2017).

$\mathrm{Na}$ Bahia, três espécies que pertencem a esses gêneros se destacam, são elas: Opuntia fícus-indica ('Gigante'), Nopalea cochenillifera ('Doce', 'Miúda' ou 'Sem espinho') e Opuntia sp. ('Orelha de onça' ou 'Redonda'). A palma 'Gigante' é a espécie mais cultivada, sendo mais difundida no semiárido (ALMEIDA, 2012).

Seu elevado potencial de produção de fitomassa e rusticidade, mesmo em condições adversas, são seus principais atributos e vantagens para utilização (Nobel, 2001; Ramos et al., 2014), representando a principal fonte de alimento disponíveis aos animais durante o período de estiagem no semiárido (SILVA et al., 2014). Possui alta palatabilidade, sendo bem aceita pelos animais (FERREIRA; URBANO, 2013). Todas essas particularidades tornam a palma forrageira, uma cultura xerófila, com maior potencial de exploração no Semiárido Brasileiro (RAMOS et al., 2014).

A palma possui grande exigência em fertilidade do solo, tal como elevada taxa de exportação de nutrientes. Sendo assim, a maior disponibilidade de nutrientes no solo pode alterar a expressão dos caracteres morfométricos e afetar o seu rendimento (DONATO et al., 2014). Sampaio (2005) verificou exigência em $\mathrm{Ca}$ e $\mathrm{Mg}$ no solo, não tendo bom desenvolvimento em solos ácidos e salinos. Para cada 10 toneladas de matéria seca produzidas, são exportados $90 \mathrm{~kg}$ de N, $16 \mathrm{~kg}$ de P, $258 \mathrm{~kg}$ de K e $235 \mathrm{~kg}$ de Ca por hectare 
(Santos et al., 1990), tornando necessária a reposição desses nutrientes ao solo.

Acrescentar esterco e outras fontes orgânicas ao solo diminui a capacidade de adsorção de fósforo, tornando-o mais disponível para absorção, também aumenta o teor de nitrogênio disponível e proporciona maior mobilidade desses nutrientes no solo (NOVAIS et al., 2007).

Diferentes trabalhos demonstraram a alta eficiência da adubação orgânica na cultura da palma forrageira. Albuquerque (2000) observou melhor resultado no uso de adubo orgânico em solos arenosos. A palma responde bem a adubação orgânica, devendo ser aplicados 20 a $40 \mathrm{t} \mathrm{ha}^{-1}$ de esterco bovino, caprino ou ovino, ou $100 \mathrm{~kg}$ de esterco para cada tonelada de matéria verde produzida (EMPARN, 2015).

Diante da importância e eficiência da adubação orgânica em palma forrageira, o presente trabalho teve como objetivo avaliar as características morfométricas e a produtividade de duas espécies de palma forrageira submetidas a diferentes doses de adubação orgânica.

\section{MATERIAL E MÉTODOS}

O experimento foi realizado no Horto Florestal, cujo local é destinado à produção de frutas, hortaliças e outras culturas que abastecem a região, localizado no município de Caetité, sudoeste baiano, latitude de $14^{\circ} 04^{\prime} 10^{\prime \prime}$ Sul e longitude $42^{\circ} 28^{\prime} 130$ " Oeste e com altitude média de aproximadamente 823 metros. O clima da região, de acordo com a classificação de Köppen (1948), é caracterizado como Aw, tropical, apresentando verão com mais pluviosidade que o inverno. A temperatura média é de $21^{\circ} \mathrm{C}$ e pluviosidade de $650 \mathrm{~mm}$. A umidade relativa da região é de $63 \%$ e a evapotranspiração de referência (ETo) média diária é de 6,50 $\mathrm{mm} \mathrm{dia}^{-1}$.

O solo da área experimental é um Latossolo Vermelho distrófico típico, com horizonte superficial A franco, textura média, na fase Caatinga hipoxerófila e com relevo caracterizado como plano a suave ondulado (EMBRAPA, 2013).

O delineamento experimental utilizado foi em blocos ao acaso em esquema fatorial $4 \times 2$, com 4 repetições, sendo quatro doses de adubação orgânica $(0 ; 25 ; 50$ e 75 t ha-1) e duas espécies de palma ('Gigante' e 'Sem espinho').

A parcela experimental foi constituída de 4 linhas de 4 metros de comprimento, espaçadas em $1 \mathrm{~m}$, totalizando a área da parcela de $16 \mathrm{~m}^{2}$. Para as avaliações foram consideradas as duas linhas centrais, avaliando-se 4 plantas por fileira, totalizando uma área útil de $0,8 \mathrm{~m}^{2}(0,4 \times 2 \mathrm{~m})$. A área total do experimento foi de $512 \mathrm{~m}^{2}$.

Aos 15 dias antes do plantio a área foi subsolada, arada, gradeada e sulcada. A adubação orgânica foi realizada no sulco de plantio, conforme as doses previstas.

O plantio dos cladódios ocorreu na primeira quinzena de agosto de 2016. Os cladódios utilizados para o plantio foram retirados de campos de produção com dois anos sem colheita e sendo colocados um cladódio ("raquete") por cova, na posição vertical a uma profundidade correspondente à metade do artículo. Os tratos culturais, foram conduzidos quando necessários, para controle de plantas daninhas foi adotado a capina manual.

A colheita foi realizada dois anos após o plantio, de forma manual, conservando-se todos os cladódios primários (mãe) e secundários (filha) na planta.

Em cada parcela experimental foram escolhidas 8 plantas nas duas fileiras centrais, a fim de analisar as características de desenvolvimento, crescimento e produtividade. As características avaliadas foram: comprimento do cladódio (CC), largura do cladódio (LC), número de cladódio $(\mathrm{NC})$, altura das plantas (ALT), altura total de cladódios (ATC), área do cladódio (AC), índice de área de cladódios (IAC), produção de massa verde (PMV) e produção de massa seca (PMS).

As características CC, LC, ATL e ATC foram obtidas com auxílio de fita métrica. Com os dados da área e do número de cladódios por planta foi calculado o Índice de Área do Cladódio (IAC). Para determinação da altura considerou-se desde o nível do solo até a extremidade do cladódio mais alto. Para determinação da largura e comprimento da raquete foram consideradas as maiores extremidades. Para as mensurações do NC foram consideradas todas as unidades emitidas pela planta.

A produção de matéria verde (PMV) foi calculada a partir da colheita e pesagem dos cladódios da área amostral $\left(0,8 \mathrm{~m}^{2}\right)$ e posterirormente convertida para toneladas por hectare. Para determinação da produção de matéria seca (PMS) foi retirada de cada planta uma amostra do material verde, onde foi contabilizado 1000 gramas de material por parcela experimental. Esse material foi levado para o laboratório, onde foi fragmentado em partículas menores com tamanho de 1 a 1,5 cm para facilitar a perda de água. Posteriormente foi colocado em bandejas de alumínio e levado para estufa com temperatura de $60^{\circ} \mathrm{C}$ por 72 horas (DETMANN et al., 2012). Logo após esse período, foi estimado os valores de amostra seca ao ar (ASA).

Posteriormente, foram retiradas das ASA uma amostra de 2 gramas de material de cada parcela experimental e acondicionada em cadinhos, deixando-os por 16 horas a $105^{\circ} \mathrm{C}$ em estufa, a fim de se obter os pesos das amostras secas em estufa (ASE). O teor de matéria seca foi determinado conforme a equação 1 :

$$
\operatorname{MS}(\%)=\frac{\left(\frac{\mathrm{ASA} \%}{\mathrm{ASE} \%}\right)}{100}
$$

em que: MS $(\%)=$ teor de matéria seca; $\mathrm{ASA}=$ amostra seca ao ar; ASE = amostra seca em estufa.

Após a determinação do teor de matéria seca o resultado foi convertido para PMS em toneladas por hectare. Os dados foram submetidos à análise de variância e teste $\mathrm{F}$ a $5 \%$ de significância. $\mathrm{O}$ teste de Tukey $(\mathrm{P}<0,05)$ foi usado para comparação das médias das cultivares e para as doses de adubo foram gerados gráficos a partir das regressões. Os procedimentos estatísticos foram realizados no programa SISVAR 5.3 (FERREIRA, 2011).

\section{RESULTADOS}

Houve efeito significativo para doses de esterco bovino em todas as características morfométricas analisadas, o fator genótipo foi significativo para NC, ALT, ATC, IAC, PMV e PMS, já a interação doses de esterco bovino versus cultivares não foi significativa pelo teste $\mathrm{F}(\mathrm{P}<0,5)$.

Para o comprimento médio dos cladódios de palma forrageira, foi possível observar um comportamento quadrático positivo do comprimento dos cladódios em função das doses de esterco aplicadas. A dose de 46,63 t ha-1 promoveu o maior comprimento de cladódio das palmas forrageiras $(32,0 \mathrm{~cm})$, havendo redução do comprimento, quando submetido a doses superiores (Figura 1). 
O mesmo comportamento foi observado para a largura (Figura 2) e área (Figura 3) do cladódio. A largura do cladódio tendeu a aumentar até a dose de 46,87 t ha-1, apresentando um valor de $14,2 \mathrm{~cm}$. A dose de 46,2 $\mathrm{t} \mathrm{ha}^{-1}$ proporcionou maior área do cladódio, $315,12 \mathrm{~cm}^{2}$. A partir desta dose é possível notar redução na largura e também na área do cladódio. $O$ número de cladódios por planta se ajustou a uma equação linear, a dose de $75 \mathrm{t} \mathrm{ha}^{-1}$ se sobressaiu entre as demais, resultando em uma média de 10,27 cladódios por planta (Figura 4).

Da mesma maneira, a maior altura das plantas $(83,8 \mathrm{~cm})$, altura dos cladódios $(58 \mathrm{~cm})$ e o maior índice de área dos cladódios $(1,40)$ foram observados na maior dose de esterco bovino (Figura 5, 6 e 7, respectivamente).

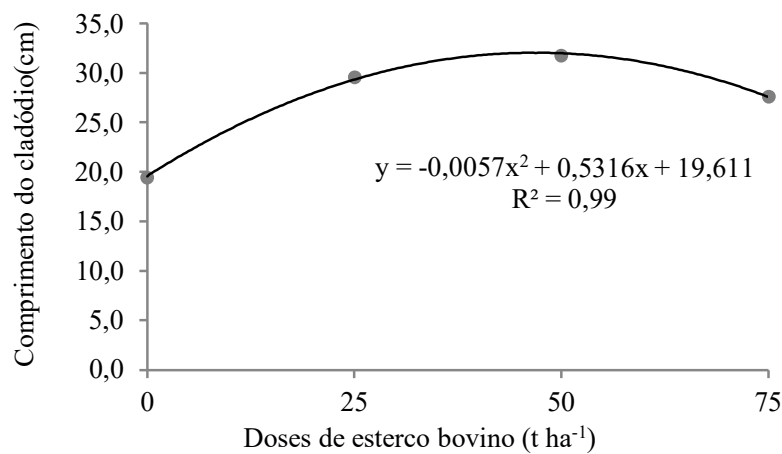

Figura 1. Comprimento do cladódio $(\mathrm{cm})$ de palma forrageira submetida a diferentes doses de esterco bovino $\left(\mathrm{t} \mathrm{ha} \mathrm{h}^{-1}\right)$, Caetité-BA. Figure 1. Cladode length $(\mathrm{cm})$ of forage palm submitted to different doses of bovine manure $\left(t h^{-1}\right)$, Caetité-BA.

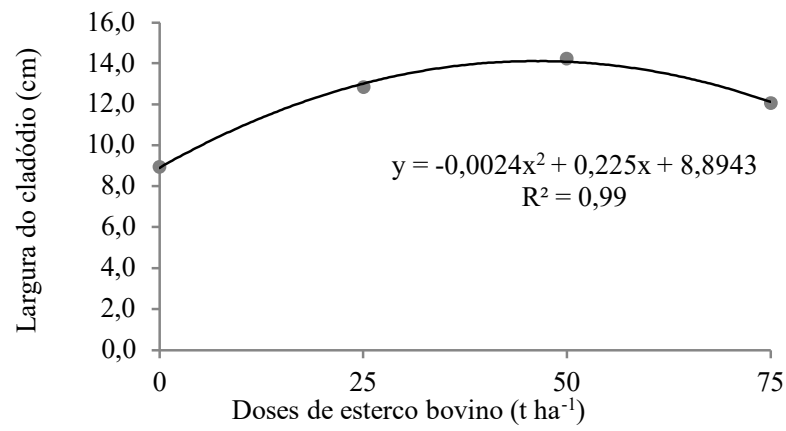

Figura 2. Largura do cladódio $(\mathrm{cm})$ de palma forrageira submetida a diferentes doses de esterco bovino ( $\left.\mathrm{t} \mathrm{ha} \mathrm{p}^{-1}\right)$, Caetité-BA.

Figure 2. Cladode width $(\mathrm{cm})$ of forage palm submitted to different doses of bovine manure $\left(\mathrm{t} \mathrm{ha}^{-1}\right)$, Caetité-BA.

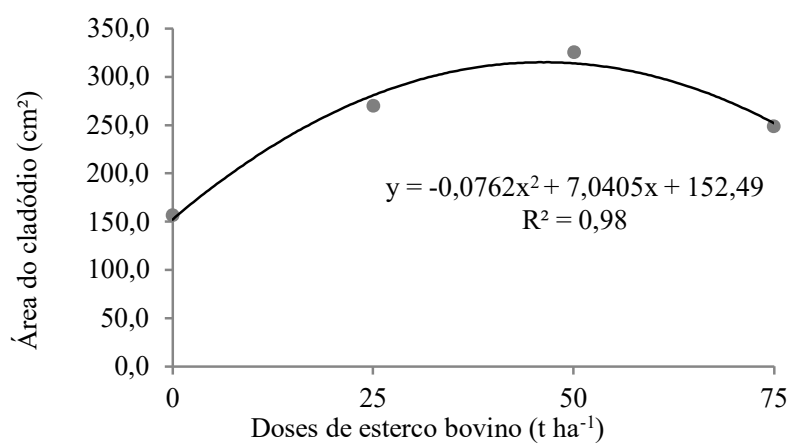

Figura 3. Área do cladódio $\left(\mathrm{cm}^{2}\right)$ de palma forrageira submetida a diferentes doses de esterco bovino $\left(\mathrm{t} \mathrm{ha}^{-1}\right)$, Caetité-BA.

Figure 3. Forage palm cladode area $\left(\mathrm{cm}^{2}\right)$ submitted to different doses of bovine manure $\left(\mathrm{t} \mathrm{ha}^{-1}\right)$, Caetité-BA.

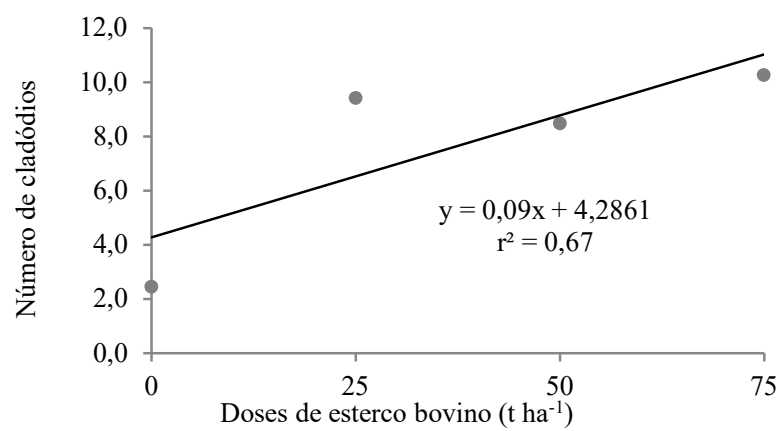

Figura 4. Número de cladódios de palma forrageira submetida a diferentes doses de esterco bovino $\left(\mathrm{t} \mathrm{ha}^{-1}\right)$, Caetité-BA.

Figure 4. Number of forage palm cladodes submitted to different doses of bovine manure $\left(\mathrm{t} \mathrm{ha}^{-1}\right)$, Caetité-BA.

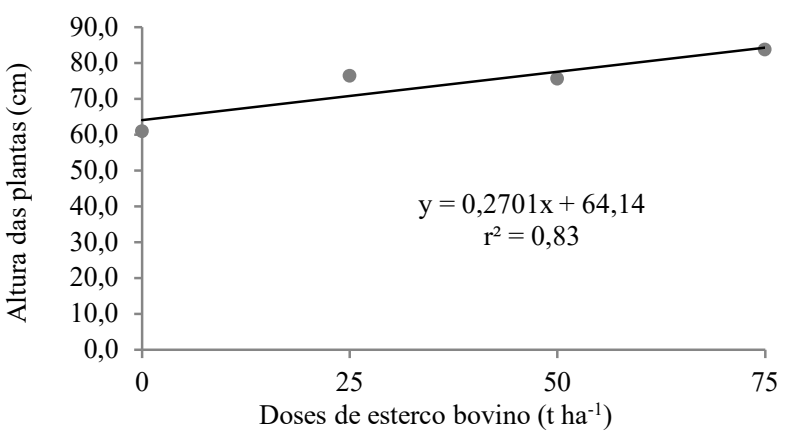

Figura 5. Altura de plantas $(\mathrm{cm})$ de palma forrageira, submetidas a diferentes doses de esterco bovino $\left(\mathrm{t} \mathrm{ha}^{-1}\right)$, Caetité-BA.

Figure 5. Height of forage palm plants $(\mathrm{cm})$ submitted to diferente doses of bovine manure $\left(\mathrm{t} \mathrm{ha}^{-1}\right)$, Caetité- BA.

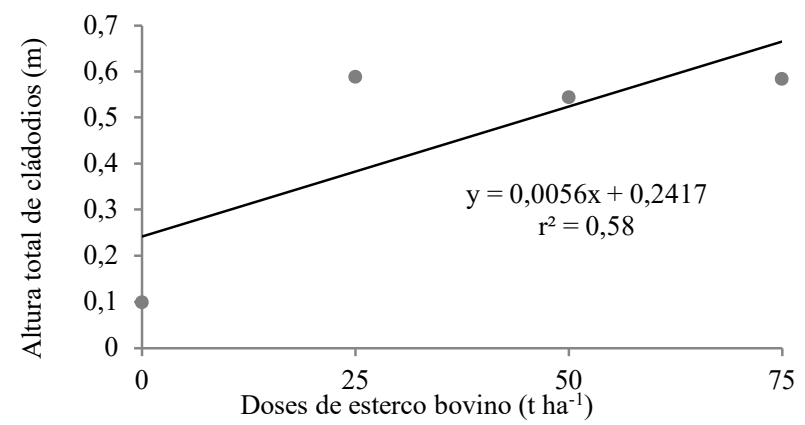

Figura 6. Altura total de cladódios ( $\mathrm{m}$ ) de palma forrageira submetida a diferentes doses de esterco bovino $\left(\mathrm{t} \mathrm{ha}^{-1}\right)$, Caetité-BA. Figure 6. Total height of forage palm cladodes (m) submitted to different doses of bovine manure $\left(\mathrm{t} \mathrm{ha}^{-1}\right)$, Caetité-BA.

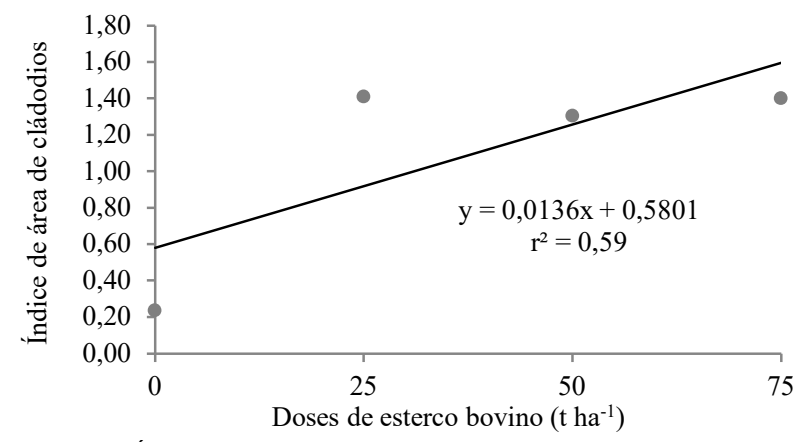

Figura 7. Índice de área de cladódios $(\mathrm{cm})$ de palma forrageira submetida a diferentes doses de esterco bovino $\left(\mathrm{t} \mathrm{ha}^{-1}\right)$, Caetité-BA. Figure 7 . Index of cladodes area $(\mathrm{cm})$ of forage palm submitted to different doses of bovine manure $\left(\mathrm{t} \mathrm{ha}^{-1}\right)$, Caetité-BA.

A produção de matéria verde e seca em função das doses pode ser explicada com uma equação linear, onde a dose de 
adubação orgânica de $75 \mathrm{t} \mathrm{ha}^{-1}$ promoveu a maior PMV (Figura 8) e PMS (Figura 9), resultando em 213,45 e 23,20 t $\mathrm{ha}^{-1}$, respectivamente.

Como o fator genótipo foi significativo pelo teste $\mathrm{F}$ para PMV e PMS, foi necessário aplicar o teste de Tukey $(\mathrm{P}<0,05)$. A palma 'Gigante' obteve maior produção de massa verde e seca em relação a 'Sem espinho', apresentando 175,91 t ha ${ }^{-1}$ matéria verde e 15,85 $\mathrm{t} \mathrm{ha}^{-1}$ de matéria seca (Figura 10 e 11, respectivamente).

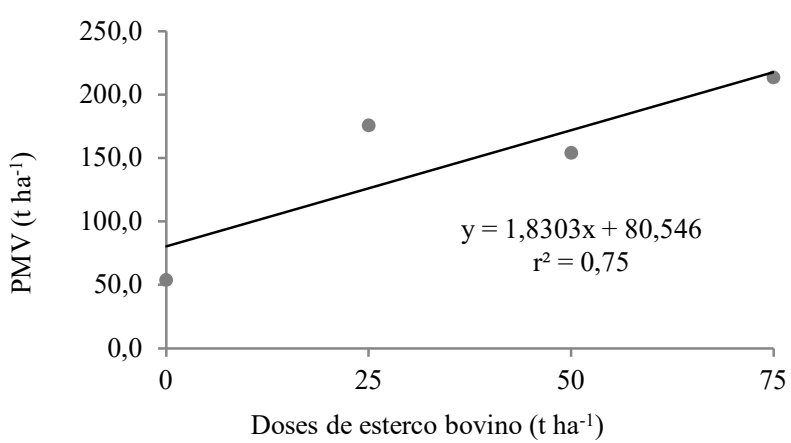

Figura 8. Produção de matéria verde $\left(\mathrm{t} \mathrm{ha}^{-1}\right)$ de palma forrageira submetida a diferentes doses de esterco bovino $\left(\mathrm{t} \mathrm{ha}^{-1}\right)$, Caetité-BA. Figure 8. Production of green matter $\left(\mathrm{t} \mathrm{ha}^{-1}\right)$ from forage palm submitted to different doses of bovine manure $\left(\mathrm{t} \mathrm{ha}^{-1}\right)$, Caetité-BA.

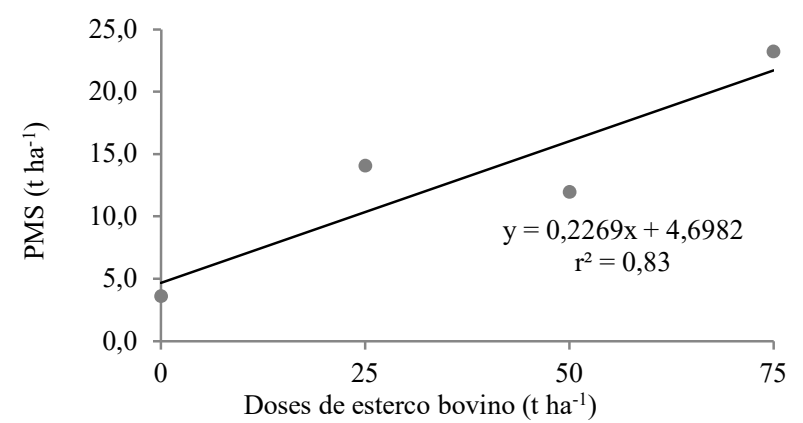

Figura 9. Produção de matéria seca $\left(\mathrm{t} \mathrm{ha}^{-1}\right)$ de palma forrageira submetida a diferentes doses de esterco bovino $\left(t \mathrm{ha}^{-1}\right)$, Caetité-BA. Figure 9. Production of dry matter $\left(\mathrm{t} \mathrm{ha}^{-1}\right)$ of forage palm submitted to different doses of bovine manure $\left(\mathrm{t} \mathrm{ha}^{-1}\right)$, Caetité-BA.

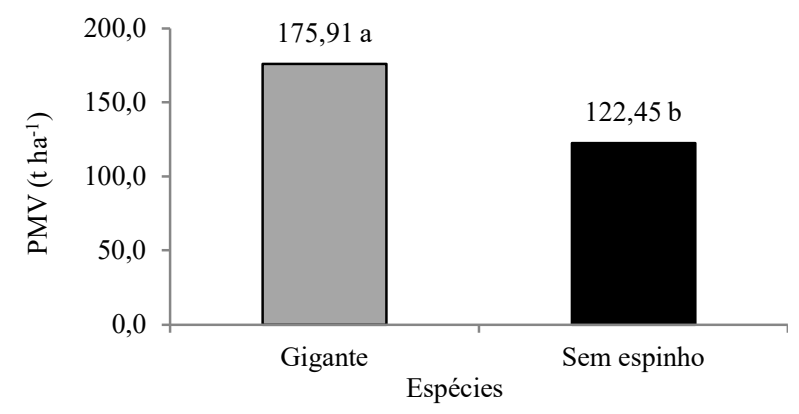

Figura 10. Produção de matéria verde $\left(\mathrm{t} \mathrm{ha}^{-1}\right)$ das espécies 'Gigante' e 'Sem espinho', Caetité-BA. Médias seguidas por letras diferentes, em cada coluna, diferem estatisticamente (Tukey, p > $0,05)$.

Figure 10. Green matter production $\left(\mathrm{t} \mathrm{ha}^{-1}\right)$ of the species 'Gigante' and 'Sem espinho', Caetité-BA. Means followed by different letters in each column differ statistically (Tukey, $\mathrm{p}>0.05$ ).

\section{DISCUSSÃO}

Os resultados obtidos de comprimento e largura de cladódio foram semelhantes aos encontrados na literatura. Barros et al. (2016) relataram que a adição de até 90 t ha ${ }^{-1}$ de esterco bovino no cultivo da palma 'Gigante' é capaz de melhorar as características produtivas, como quantidade de cladódios por planta, altura, produção de massa verde e seca. (Ferreira et al. (2003) trabalhando com palma forrageira 'Gigante' sob diferentes doses de adubação química e/ou orgânica, verificaram largura média de cladódios de 17,4 cm aos 510 DAP e $18,3 \mathrm{~cm} 720 \mathrm{DAP}$, respectivamente.

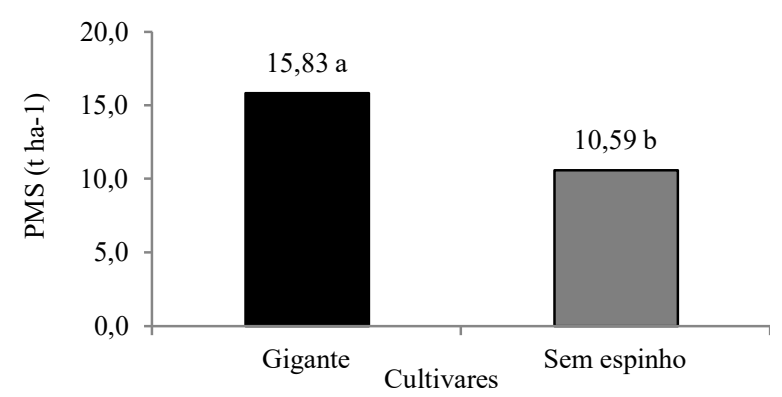

Figura 11. Produção de matéria seca ( $t$ ha $\left.{ }^{-1}\right)$ das espécies 'Gigante' e 'Sem espinho', Caetité-BA. Médias seguidas por letras diferentes, em cada coluna, diferem estatisticamente (Tukey, $\mathrm{p}>0,05)$.

Figure 11. Green matter production $\left(\mathrm{t} \mathrm{ha}^{-1}\right)$ of the cultivars 'Gigante' and 'Sem espinho', Caetité-BA. Means followed by different letters in each column differ statistically (Tukey, $\mathrm{p}>0.05$ ).

Donato et al. (2014) trabalhando com palma 'Gigante' submetida a diferentes espaçamentos e doses de adubação observaram que a área dos cladódios avaliados aos 600 DAP, não diferiu entre as doses de esterco. Esse resultado difere do encontrado no presente trabalho que indica interação significativa entre os fatores.

A equação linear obtida entre a dose de adubação e o número de cladódio demonstra que a cada $11 \mathrm{t} \mathrm{ha}^{-1}$ de esterco bovino adicionado ao solo proporciona o aumento de 1 cladódio. O aumento do número de cladódio com a dose de adubação orgânica também foi observado por Almeida (2011) avaliando palma forrageira 'Gigante' no segundo ano após o plantio constatou valores médios de 12,5 e 16 cladódios por planta, sem adubação e com adubação de $30 \mathrm{t}$ $\mathrm{ha}^{-1} \mathrm{ano}^{-1}$ de esterco bovino, respectivamente.

A altura das plantas e a altura total de cladódios teve um incremento linear da dose zero até a dose de $75 \mathrm{t} \mathrm{ha}^{-1}$ de adubação. Entre a ausência do adubo e a maior dose aplicada a altura total de cladódios variou em $42 \mathrm{~cm}$ e a altura das plantas em 20,26 cm.

$O$ índice de área foliar é um parâmetro indireto de produção já que um maior índice indica uma maior capacidade de realizar fotossíntese e consequentemente um maior potencial produtivo, dessa forma o incremento na dose de adubação proporcionou melhores resultados. A cada $10 \mathrm{t}$ $\mathrm{ha}^{-1}$ de esterco bovino aplicado proporcionou um aumento de 0,136 do índice da área foliar, sendo que a dose de $75 \mathrm{tha}$ ${ }^{1}$ obteve o valor de 1,6.

Com o aumento da dose de adubo orgânico aumentou também a PMV e PMS. A produção de uma cultura normalmente responde de forma quadrática à dose de adubação, obedecendo à lei do máximo de fertilidade do solo (VOISIN, 1973), a resposta linear encontrada no presente trabalho é um indicativo que a dose máxima e a ideal para as espécies estudadas está acima das testadas. A dose de 75 t ha1 de esterco bovino promoveu um incremento de 137,27 tha1 de matéria verde em relação a dose zero. Já a diferença da PMS entre a dose zero e a maior dose foi de 17,01 $\mathrm{t} \mathrm{ha} \mathrm{h}^{-1}$. A dose de $75 \mathrm{t} \mathrm{ha}^{-1}$ de adubo orgânico promoveu uma PMS de 
21,71 tha- $\mathrm{t}^{-1}$ esse resultado corrobora com o encontrado por Donato (2014), onde a aplicação de 71,8 t ha $\mathrm{hano}^{-1} \mathrm{de}$ esterco bovino atingiu uma produção máxima de matéria seca de 21,8 t ha $^{-1}$.

Quando analisamos as espécies independente das doses de adubação, podemos aferir que houve diferenças significativas para a PMV e PMS. A palma forrageira 'Gigante' tem maior potencial produtivo quando comparada à 'Sem espinho' produzindo a mais $53,46 \mathrm{t} \mathrm{ha}^{-1}$ de matéria verde e 5,24 tha- de matéria seca. Esse resultado é divergente do encontrado por Silva et al. (2014) que concluiu que a palma 'Sem espinho' apresenta maior potencial produtivo quando comparada a 'Gigante' em diferentes densidades de plantio. É importante ressaltar que os trabalhos foram desenvolvidos em ambientes diferentes e uma possível explicação para a inversão da produtividade das espécies é a interação genótipo x ambiente já que a produtividade é uma característica controlada por muitos genes e consequentemente muito afetada pelo ambiente.

\section{CONCLUSÕES}

A maior produção de matéria seca $\left(23,20 \mathrm{t} \mathrm{ha}^{-1}\right)$ ocorreu na dose de $75 \mathrm{t} \mathrm{ha}^{-1}$ de esterco bovino, mas essa mesma dose provoca redução nas características: comprimento do cladódio, largura do cladódio e área do cladódio.

A palma 'Gigante' apresenta uma maior produção de matéria seca $\left(15,83 \mathrm{t} \mathrm{ha}^{-1}\right)$ quando comparada a 'Sem espinho' $\left(10,59 \mathrm{tha}^{-1}\right)$.

\section{REFERÊNCIAS}

ALBUQUERQUE, S. G. D. Cultivo da palma forrageira no Sertão do São Francisco. Embrapa Semiárido 6 p. Comunicado Técnico. (INFOTECA-E), 2000.

ALMEIDA, J.; PEIXOTO, C. P.; LEDO, C. A. S. Caracterização do sistema de produção e utilização da palma forrageira na região semiárida do estado da Bahia. Centro Científico Conhecer, Goiânia, v. 8, n. 15, p. 394-404, 2012.

BARROS, J. L.; DONATO, S. L. R.; GOMES, V. M.; DONATO, P. E. R.; SILVA, J. A.; PADILHA JÚNIOR, M. C. Palma Forrageira 'Gigante' Cultivada com Adubação Orgânica. Revista Agrotecnologia, Lavras, v. 7, n. 1, p. 53-65, 2016. DOI: 10.12971/21795959/agrotecnologia.v7n1p53-65

DETMANN, E.; SOUZA, M. A. de; VALADARES FILHO, S. C.; QUEIROZ, A. C.; BERCHIELLI, T. T.; SALIBA, E. O. S.; CABRAL, L. S.; PINA, D. S.; LADEIRA, M. M.; AZEVEDO, J. A. G. (Ed.). Métodos para análise de alimentos. Visconde do Rio Branco: Suprema, 2012. 214p.

DONATO, P. E. R.; PIRES A. J. V.; DONATO S. L. R.; BONOMO P.; SILVA J. A.; AQUINO, A. A. Morfometria e rendimento da palma forrageira 'Gigante' sob diferentes espaçamentos e doses de adubação orgânica. Revista Brasileira de Ciências Agrárias, Recife, v. 9, n. 1, p. 151-158, 2014. DOI: 10.5039/agraria.v9i1a3252

EMPARN_Empresa de Pesquisa Agropecuária do Rio Grande do Norte. Palma Forrageira: irrigada e adensada. Natal: EMPARN, 2015. 62p.

EMBRAPA_EMPRESA BRASILEIRA DE PESQUISA AGROPECUÁRIA. Sistema Brasileiro de
Classificação de Solos. 3 ed. Rio de Janeiro: Embrapa Solos, 2013. 353p.

FERREIRA, C. A.; FERREIRA, R. L. C.; SANTOS, D. C. et al. Utilização de técnicas multivariadas na avaliação da divergência genética entre clones de palma forrageira (Opuntia ficus-indica Mill.). Revista Brasileira de Zootecnia, Viçosa, v. 32, n. 6, p. 1560-1568, 2003. DOI: https://doi.org/10.1590/S1516-35982003000700004.

FERREIRA, D. F. Sisvar: a computer statistical analysis system. Ciência e Agrotecnologia, Lavras, v. 35, n. 6, p. 1039-1042, 2011.2 DOI: http://dx.doi.org/10.1590/S1413-70542011000600001

FERREIRA, M. A.; URBANO, S. A. Novas Tecnologias para Alimentação de Bovinos Leiteiros na Seca. Revista Científica de Produção Animal, Areia, v. 15, n. 1, p. 4252, 2013. DOI: http://dx.doi.org/10.15528/21764158/rcpa.v15n1p42-52

KÖPPEN, W. Climatologia: con un estudio de los climas de la tierra. Fondo de Cultura Econômica. México. 479p. 1948.

MARQUES, O. F. C.; GOMES, L. S. P.; MOURTHÉ, M. H. F.; BRAZ, T. G. S.; PIRES NETO, O. D. S. Palma forrageira: cultivo e utilização na alimentação de bovinos. Caderno de Ciências Agrárias, Montes Claros, v. 9, n. 1, p. 75-93, $2017 . \quad$ DOI: http:/ /dx.doi.org/10.35699/2447-6218.2017.2940

NOBEL, P. S. Biologia ambiental. In: BARBERA, G; INGLESE, P.; PIMIENTA BARROS, E. Agroecologia, cultivo e usos da palma forrageira. João Pessoa: FAO, SEBRAE/PB, 2001. p. 36-48.

NOVAIS, R. F.; ALVAREZ, V. V. H.; BARROS, N. F.; FONTES, R. L. F.; CANTARUT'TI, R. C.; NEVES, J. C. L. (Ed.). Fertilidade do Solo. Viçosa: Sociedade Brasileira de Ciência do Solo, 2007. 64p.

RAMOS, J. P. F.; SANTOS, E. M.; FREITAS, F. F.; CÂNDIDO, E. P.; LIMA JÚNIOR, A. C.; LEITE, M. L. V.; OLIVEIRA JÚNIOR, S. Caracterização técnica dos sistemas de produção de palma forrageira em Soledade, PB. Revista Agropecuária Técnica, Areia, v. 35, n. 1, p. 23-30, 2014.

SAMPAIO, E. V. S. B. Fisiologia da palma. In; MENEZES, R. S. C. et al. (Eds). A palma no Nordeste do Brasil: conhecimento atual e novas perspectivas de uso. Recife: Editora Universitária da UFPE, 2005. p. 43-55.

SANTOS, M. V. F.; LIRA, M. A.; FARIAS, I.; BURITY, H. A.; NASCIMENTO, M. M. A.; TAVARES FILHO, J. J. Estudo comparativo das cultivares de palma forrageira 'Gigante', 'Redonda' (Opuntia fícus-índica, Mill) e 'Miúda' (Nopalea cochenillifera, Salmi Dyck) na produção de leite. Revista da Sociedade Brasileira de Zootecnia, Viçosa, v. 19, n. 6, p. 504-511, 1990.

SILVA, L. M. da; FAGUNDES, J. L.; VIEGAS, P. A. A.; MUNIZ, E. N.; RANGEL, J. H. de A., MOREIRA, A. L., BACKES, A. A. Produtividade da palma forrageira cultivada em diferentes densidades de plantio. Revista Ciência Rural, v. 44, n. 11, p. 2064-2071, 2014. DOI: http://dx.doi.org/10.1590/0103-8478cr20131305

SILVA, T. G. F.; ARAÚJO PRIMO, J. T.; MORAIS, J. E. F.; DINIZ, W. J. S.; SOUZA, C. A. A.; SILVA, M. C. Crescimento e produtividade de clones de palma forrageira no semiárido e relações com variáveis meteorológicas. Revista Caatinga, Mossoró, v. 28, n. 2, p. 10-18, 2015. 
SOARES, M. S. Palma forrageira: Aspecto do cultivo e desempenho animal. Nutritime Revista Eletrônica, Viçosa, v. 14, n. 4, p. 6041-6055, 2017.

VOISIN, A. Adubos: novas leis científicas de sua aplicação. Ed. Mestre Jou. São Paulo. 1973. 130p. 